\title{
PANDANGAN HUKUM POSITUF TERHADAP PERTANGGUNGJAWABAN HARTA PEMEGANG SAHAM PERSEROAN TERBATAS DI INDONESIA
}

\author{
Muhammad Hanavie Haikal* \\ Universitas Negeri Semarang \\ *Correspondent Email : haihav88@students.unnes.ac.id
}

Naskah diterima: 29/10/2021, Revisi: 15/11/2021, Disetujui: 31/12/2021

\begin{abstract}
Abstrak
Perseroan terbatas (PT) merupakan sebuah badan usaha berbadan hukum. Hal yang menjadi sifat pembeda dari sebuah badan hukum adalah terdapat pemisahan antara harta kekayaan yang dimiliki oleh badan hukum dan harta kekayaan pribadi yang dimiliki oleh para pemegang saham. Oleh karena itu, para pemegang saham tersebut tidak memiliki tanggung jawab pribadi secara langsung atas perikatan yang dibuat dengan nama badan hukum. Terdapat beberapa pengaturan, seperti Kitab Undang-Undang Hukum Dagang (KUHD), UU PT No. 1 Tahun 1995 jo. UU PT No. 40 Tahun 2007, dan Pasal 153J ayat (1) UU Cipta Kerja yang menyatakan bahwa pemegang saham menganut sifat terbatas pada saham yang dimiliki, kecuali jika terbukti adanya pencampuran harta pribadi milik pemegang saham dengan harta kekayaan perseroan, maka tanggung jawab tersebut menjadi tanggungan pribadi atau tidak terbatas. Oleh karena itu, penulisan jurnal berjudul "Pandangan Hukum Positif Terhadap Pertanggungjawaban Harta Pemegang Saham Perseroan Terbatas Di Indonesia” ini ditujukan untuk membahas batasan-batasan dan hal-hal yang terkait dengan pertanggungjawaban harta pemegang saham perseroan terbatas. Hal ini dimaksudkan agar nantinya para pemegang saham dapat mengetahui perilaku apa saja yang dapat menyebabkan hapusnya limited liability pada pemegang saham perseroan terbatas.
\end{abstract}

Kata Kunci: Perseroan Terbatas; Pertanggungjawaban; Pemegang Saham

\section{PENDAHULUAN}

\section{Latar Belakang}

Indonesia merupakan sebuah negara kesatuan berbentuk Negara Kesatuan Republik Indonesia (NKRI). Unsur yang melatarbelakangi terjadinya hal tersebut adalah melimpahnya pulau, suku, adat istiadat, serta keyakinan yang dianut oleh masyarakatnya. Kemudian, hal yang menjadi dasar pemilihan Indonesia sebagai negara kesatuan bukanlah sebuah kepentingan politik semata, melainkan didasari

\section{How to cite:}

Haikal, M. H. (2022). Pandangan Hukum Positif Terhadap Pertanggungjawaban Harta Pemegang Saham Perseroan Terbatas di Indonesia. Ikatan Penulis Mahasiswa Hukum Indonesia Law Journal, 1(2)

Diterbitkan oleh:

Ikatan Penulis Mahasiswa Hukum Indonesia 
oleh sebuah komitmen untuk persatuan dan keadilan. Hal ini juga diperjelas oleh pernyataan yang disebutkan dalam Pasal 1 ayat (1) UUD 1945 yang berbunyi, "Negara Indonesia ialah negara kesatuan, yang berbentuk republik". ${ }^{1}$ Kemudian, ketentuan-ketentuan yang terkait dengan undang-undang sebelumnya dijelaskan lebih lanjut dalam Pasal 18 ayat (1) UUD 1945 yang berbunyi, "Negara Kesatuan Republik Indonesia dibagi atas daerah-daerah provinsi dan daerah provinsi itu dibagi atas kabupaten dan kota, yang tiap-tiap provinsi, kabupaten, dan kota itu mempunyai Pemerintahan daerah, yang diatur dengan Undang-Undang.

Setiap negara di belahan dunia ini pastinya memiliki sebuah sistem hukum yang mengatur tata pemerintahannya. Negara Kesatuan Republik Indonesia (NKRI) merupakan salah satu negara yang menganut sistem hukum civil law. Sistem hukum civil law sendiri merupakan sebuah sistem hukum yang dibawa oleh Belanda pada saat zaman penjajahan di Indonesia. Jangka waktu pendudukan Belanda yang begitu lama menyebabkan imperialisme yang dilakukan oleh Belanda kepada Indonesia meninggalkan banyak sekali jejak peninggalan, terlebih dalam bidang hukum. Belanda yang memiliki landasan civil law dari Prancis yang kemudian memberlakukan kembali civil law tersebut kepada Indonesia. Oleh karena itu, Indonesia pada kenyataannya lebih banyak terpengaruh oleh hukum Prancis. Melekatnya keberadaan hukum yang dibawa oleh Belanda, seperti misalnya kitab perundang-undangan, terjadi karena adanya asas konkordansi yang berlaku di Indonesia. Asas konkordansi sendiri memiliki pengertian bahwa asas tersebut merupakan asas yang menjadi dasar untuk keberlakuan hukum yang berlaku di Eropa atau Belanda saat itu untuk diimplementasikan juga terhadap orang-orang pribumi/Indonesia. Dengan demikian, hukum Eropa yang menjadi landasan kubu Belanda pada saat itu, diberlakukan di Indonesia. Oleh karena itu, sudah jelas bahwa asas konkordansi merupakan asas berlakunya hukum Belanda pada saat itu terhadap bangsa Indonesia.

Di Indonesia sendiri, undang-undang yang pertama kali mengatur tentang eksistensi perseroan terbatas (PT) adalah Kitab Undang-Undang Hukum Dagang (KUHD) yang merupakan kodifikasi undang-undang dari Belanda yang disebut Wetboek Van Koophandel (WVK). Pengaturan tentang perseroan terbatas dalam kitab undang-undang tersebut pertama kali diatur di dalam Pasal 36 sampai Pasal 56 Kitab Undang-Undang Hukum Dagang (KUHD). Kemudian, pada tahun 1995, Indonesia akhirnya memiliki undang-undangnya sendiri terkait dengan perseroan terbatas (PT), yaitu Undang-Undang Nomor 1 Tahun 1995 tentang Perseroan Terbatas (PT). Kemudian, Undang-Undang Nomor 1 Tahun 1995 tentang Perseroan Terbatas (PT) digantikan oleh undang-undang yang baru, yaitu Undang-Undang Nomor 40 Tahun 2007 tentang Perseroan Terbatas (PT), atau dalam perspektif hukum dagang lebih dikenal dengan UU PT. Undang-Undang Nomor 40 Tahun 2007 tentang Perseroan Terbatas (PT) atau UU PT tersebut diberlakukan sejak tanggal 16 Agustus tahun 2007. Selanjutnya, terdapat perundang-undangan yang paling baru untuk memperbaharui beberapa poin peraturan perundang-undangan yang telah disebutkan sebelumnya, yaitu Undang-Undang Nomor 40 Tahun 2007 tentang Perseroan Terbatas (PT) atau UU PT. Untuk memperbaharui beberapa poin undang-undang tersebut, Presiden Joko Widodo bersama dengan Dewan Perwakilan Rakyat Republik Indonesia (DPR RI) mengesahkan dan memberlakukan undang-undang yang baru, yaitu Undang-Undang Nomor 11

${ }^{1}$ UUD 1945, UUD 1945 Pasal 1 ayat (1). 
Tahun 2020 tentang Cipta Kerja, atau biasa disebut dengan Undang-Undang Cipta Kerja (UU CK). Undang-Undang Cipta Kerja (UU CK) tersebut mulai diberlakukan sejak tanggal 2 November tahun 2020 lalu. Dengan diberlakukannya undangundang ini, beberapa poin penting terkait Undang-Undang Nomor 40 Tahun 2007 tentang Perseroan Terbatas (PT) telah diubah ketentuannya.

Perseroan terbatas (PT) merupakan sebuah badan usaha berbadan hukum. Hal yang menjadi sifat pembeda dari sebuah badan hukum adalah terdapat pemisahan antara harta kekayaan yang dimiliki oleh badan hukum dan harta kekayaan pribadi yang dimiliki oleh para pemegang saham. Oleh karena itu, para pemegang saham tersebut tidak memiliki tanggung jawab pribadi secara langsung atas perikatan yang dibuat dengan nama badan hukum. Kemudian, para pemegang saham juga tidak bertanggung jawab atas kerugian badan hukum melebihi jumlah saham yang telah diinvestasikannya. ${ }^{2}$ Di dalam hukum dagang, istilah ini dikenal sebagai tanggung jawab terbatas. Perseroan terbatas (PT) adalah jenis badan usaha yang paling banyak diminati di kalangan masyarakat luas. Dengan demikian, badan usaha yang berbentuk perseroan terbatas (PT) terbilang lebih banyak jumlahnya jika dibandingkan dengan jumlah jenis badan usaha yang lain. Kemudian, selain mengacu pada pertimbangan ekonomi, hal-hal yang menjadi latar belakang dipilihnya perseroan terbatas (PT) sebagai badan usaha adalah saham sebagai modal, terdapat pemisahan kekayaan terhadap pemegang saham, terdapat batasan tanggung jawab pemegang saham, pemegang saham memiliki fungsi yang berbeda dengan bagian dewan pengurus atau dewan direksi, terdapat komisaris yang bertugas sebagai pengawas, dan Rapat Umum Pemegang Saham (RUPS) sebagai kekuasaan tertinggi di perseroan terbatas (PT).

Perseroan terbatas (PT) merupakan salah satu organ utama kehidupan masyarakat modern, karena merupakan salah satu pusat aktivitas manusia untuk memenuhi kehidupannya sehari-hari. Kegiatan perusahaan adalah bagian dari kegiatan ekonomi yang dilakukan oleh suatu organisasi, secara terbuka dan terus menerus, melibatkan barang, baik yang bergerak maupun tidak bergerak atau di bidang jasa. Dalam hal ini, perusahaan tentunya bersaing dalam segi kualitas dan kuantitas atau dalam aspek menggali keuntungan atau laba.

Tujuan didirikannya badan usaha perseroan terbatas (PT) adalah untuk mengoperasikan suatu jenis usaha dengan permodalan tertentu yang dibagi-bagi ke dalam bentuk saham yang kemudian para pemegang saham tersebut ikut mengambil bagiannya paling sedikit berjumlah satu lembar saham, lalu pemegang saham tersebut dapat menjalankan beberapa perbuatan hukum yang dibuat atas nama bersama. Selanjutnya, pemegang saham tidak boleh memikul tanggung jawab sendirian karena terdapat pertanggungjawaban yang terbatas sebanyak saham yang dimiliki. Perseoran terbatas (PT) tentunya harus memiliki tujuan usaha yang jelas, serta melakukan proses usaha yang tidak berlawanan dengan ketentuan-ketentuan yang terdapat dalam undang-undang, ketentraman dan ketertiban masyarakat, serta moral dan etika dalam kehidupan bermasyarakat.

\section{Perumusan Masalah}

1. Bagaimana dan apa kewajiban pemegang saham perseroan terbatas sesuai dengan hukum positif dan kapan kewajiban pemegang saham bergeser dari terbatas menjadi tidak terbatas?

${ }^{2}$ UU PT 2007 Pasal 3 ayat (1), UU Nomor 40 Tahun 2007 Pasal 3 ayat (1). 


\begin{abstract}
METODE
Metode penelitian yang digunakan adalah dengan penelitian hukum normatif serta menggunakan pendekatan peraturan perundang-undangan (statue approach) dan pendekatan kasus (case approach). Kemudian, jenis data yang digunakan meliputi bahan hukum primer seperti peraturan perundang-undangan yang berkaitan dengan TPPU, bahan hukum sekunder, dan bahan hukum tersier. Dari bahan-bahan hukum tersebut, maka akan diinventarisir oleh penulis dengan menggunakan metode studi kepustakaan untuk mendapatkan preskripsi atas isu hukum yang diangkat.
\end{abstract}

\title{
HASIL PENELITIAN DAN PEMBAHASAN
}

\section{PENGERTIAN PERSEROAN TERBATAS SECARA UNIVERSAL}

Perseroan terbatas (PT), merupakan sebuah badan usaha berbadan hukum yang berdiri karena adanya suatu perjanjian untuk menjalankan suatu kegiatan usaha berdasarkan modal dasar yang bentuk keseluruhannya dibagikan dalam bentuk saham. Hal ini juga menjadi landasan istilah "terbatas" di dalam perseroan terbatas "PT" karena terdapat batasan tanggung jawab yang dimiliki oleh pemegang saham tersebut. Perseroan terbatas (PT) pertama kali diperkenalkan dalam bahasa Belanda, yaitu naamloze vennootschap atau dapat disingkat menjadi "NV". Jika dalam bahasa Indonesia "PT" diletakkan sebelum nama perusahaan, dalam bahasa Belanda terdapat perbedaan, yaitu "NV" diletakkan setelah nama perusahaan.

Definisi perseroan terbatas "PT" menurut Undang-Undang Nomor 1 Tahun 1995 adalah: "Perseroan Terbatas yang selanjutnya disebut perseroan adalah badan hukum yang didirikan berdasarkan perjanjian, melakukan kegiatan usaha dengan modal dasar yang seluruhnya terbagi dalam saham, dan memenuhi persyaratan yang ditetapkan dalam Undang-undang ini serta peraturan pelaksanaannya". ${ }^{3}$ Definisi tersebut juga kurang lebih sama saja seperti yang tertera di dalam Undang-Undang Nomor 40 Tahun 2007 tentang Perseroan Terbatas. Kemudian, terdapat sedikit tambahan terhadap definisi tersebut setelah diundangkannya Undang-Undang Nomor 11 Tahun 2020 (UU CK) yang berbunyi, "Perseroan Terbatas, yang selanjutnya disebut Perseroan, adalah badan hukum yang merupakan persekutuan modal, didirikan berdasarkan perjanjian, melakukan kegiatan usaha dengan modal dasar yang seluruhnya terbagi dalam saham atau Badan Hukum perorangan yang memenuhi kriteria Usaha Mikro dan Kecil sebagaimana diatur dalam peraturan perundang-undangan mengenai Usaha Mikro dan Kecil". Kemudian, perseroan harus mempunyai maksud dan tujuan serta kegiatan usaha yang tidak bertentangan dengan ketentuan peraturan perundangundangan, ketertiban umum, dan/atau kesusilaan. ${ }^{5}$ Selanjutnya, perseroan memperoleh status badan hukum setelah didaftarkan kepada menteri dan mendapatkan bukti pendaftaran. ${ }^{6}$

Perundang-undangan yang mengatur tentang perseroan terbatas (PT) pertama kali diundangkan dalam Kitab Undang-Undang Hukum Dagang (KUHD) atau Wetboek Van Koophandel (WVK), selanjutnya hal ini diatur

\footnotetext{
${ }^{3}$ UU RI, Undang-Undang Nomor 1 Tahun 1995 tentang Perseroan Terbatas.

${ }^{4}$ UU CK 2020 Pasal 109 ayat (1), UU Cipta Kerja Pasal 109 ayat (1).

${ }^{5}$ UU PT 2007 Pasal 2, UU Nomor 40 Tahun 2007 Pasal 2.

${ }^{6}$ UU CK 2020 Pasal 109 ayat (2), UU Cipta Kerja Pasal 109 ayat (2).
} 
dalam perundang-undangan yang murni pertama kali dibuat oleh Indonesia, yaitu Undang-Undang Nomor 1 Tahun 1995 tentang Perseroan Terbatas (PT). Kemudian diperbaharui pada tahun 2007 dengan Undang-Undang Nomor 40 Tahun 2007 tentang Perseroan Terbatas (UU PT). Lalu, terbitlah UndangUndang Nomor 11 Tahun 2020 tentang Cipta Kerja untuk memperbaharui beberapa poin penting terkait ketentuan perseroan terbatas (PT) di dalam Undang-Undang Nomor 40 Tahun 2007 tentang Perseroan Terbatas (UU PT).

\section{ELEMEN-ELEMEN DARI PERSEROAN TERBATAS}

\section{a. Badan Hukum (Rechtpersoon)}

Menurut Prof. R. Subekti, badan hukum merupakan sebuah badan atau sebuah perkumpulan yang di dalamnya terdapat hak untuk melakukan perbuatan layaknya manusia, memiliki harta kekayaan pribadi, dan dapat menggugat atau digugat di hadapan hakim. Badan hukum atau rechtpersoon adalah sebuah wadah atau organisasi yang didirikan dengan sebuah akta otentik. Kemudian, organisasi ini juga diperlakukan sebagai orang yang memiliki hak serta kewajiban dalam aspek hukum, atau dapat dikatakan pula sebagai sebuah subyek hukum tak berwujud, atau wujudnya tidak terlihat seperti orang biasa, namun tetap memiliki hak serta kewajiban dalam melakukan perbuatan hukum seperti orang pribadi (naaturlijk persoon). ${ }^{7}$ Terdapat tiga bentuk badan hukum berdasarkan kedudukannya, yaitu badan hukum yang dibentuk oleh pemerintah, badan hukum yang diakui oleh pemerintah, dan badan hukum yang memiliki tujuan tertentu. ${ }^{8}$ Terdapat pula badan hukum yang cakap dan tidak cakap. Hal ini dapat diketahui dari kewenangannya.

\section{b. Pendirian Berlandaskan Perjanjian}

Jika dilihat dari segi perspektif hukum perjanjian, pendirian sebuah perseroan terbatas (PT) sebagai badan hukum memiliki wujud kontraktual, yaitu penyebab berdirinya sebuah perseroan terbatas (PT) adalah dari sebuah perjanjian. Kemudian pendirian ini juga memiliki wujud konsensual, yaitu terdapat sebuah persetujuan untuk mengikat perjanjian dalam mendirikan sebuah perseroan terbatas (PT). Dalam hal ini, pendirian perseroan terbatas yang merupakan sebuah persekutuan modal yang terdapat di antara pendiri perusahaan atau para pemegang saham harus memenuhi hukum-hukum yang mengatur perjanjian seperti yang terdapat di dalam Kitab Undang-Undang Hukum Perdata (KUH Perdata), khususnya buku ketiga tentang ketentuanketentuan umum perjanjian, syarat sahnya sebuah perjanjian, dan yang terakhir adalah mengenai akibat dari sebuah perjanjian. Terdapat empat syarat untuk diakui sahnya sebuah perjanjian dalam Kitab Undang-Undang Hukum Perdata (KUH Perdata), yaitu: ${ }^{9}$

1) Sepakat mereka yang mengikatkan dirinya;

2) Kecakapan untuk membuat suatu perikatan;

3) Suatu hal tertentu;

4) Suatu sebab yang halal.

\section{c. Melakukan Sebuah Kegiatan Usaha}

Sebuah perusahaan seperti perseroan terbatas (PT), tentunya harus melakukan sebuah kegiatan usaha. Kegiata usaha merupaka sebuah bentuk

\footnotetext{
${ }^{7}$ Pengetahuan, "Pengertian Badan Hukum, Ciri, Bentuk, Jenis Dan Teorinya."

${ }^{8}$ Subekti and Tjitrosudibio, "Kitab Undang-Undang Hukum Perdata Pasal 1653."

${ }^{9}$ Subekti and Tjitrosudibio, "Kitab Undang-Undang Hukum Perdata Pasal 1320."
} 
kegiatan yang dilakukan oleh perorangan ataupun bersekutu yang memiliki hubungan terhadap transaksi jual-beli barang atau jasa, dan memiliki tujuan supaya mendapatkan keuntungan berupa penghasilan atau pendapatan. Walaupun kegiatan usaha memiliki tujuan utama untuk mendapatkan keuntungan atau laba, namun bukan berarti perusahaan yang melakukan kegiatan usaha hanya menargetkan tujuan tersebut. Terdapat macam-macam tujuan berkegiatan usaha yang ingin diraih oleh para pelaku usaha tersebut. Salah satu tujuan yang penulis ketahui adalah untuk memenuhi kebutuhankebutuhan barang atau jasa untuk para konsumen ataupun masyarakat luas. Selain untuk meramaikan pasar, perbandingan harga yang diberikan oleh si pelaku usaha juga menjadi pengaruh besar untuk kegiatan usaha yang dilakukan.

\section{d. Modal dasar yang dibagi-bagikan dalam bentuk saham}

Modal dasar yang dimaksud di sini adalah modal awal untuk mendirikan sebuah perseroan terbatas (PT). Sebuah perseroan terbatas (PT), tentunya harus memiliki modal dasar untuk mendirikan perusahaan dan melakukan kegiatan usahanya. Modal dasar untuk mendirikan sebuah perseroan terbatas (PT) harus berupa saham. Modal dasar ini juga merupakan kekayaan perseroan terbatas (PT) sebagai badan hukum yang terpisah dari kekayaan milik pribadi para pendiri, para pemegang saham, dan juga organorgan lain dalam perseroan terbatas.

\section{e. Memenuhi persyaratan dalam perundang-undangan}

Terdapat beberapa ketentuan perundang-undangan yang harus dipenuhi dalam mendirikan perseroan terbatas (PT), seperti hal berikut: Dilaksanakan dengan sistem atau metode tertutup; Mematuhi persyaratan mulai dari awal perusahaan didirikan, saat beroperasi, dan saat berakhirnya perusahaan; Terdapat syarat yang wajib dilakukan seperti akta pendirian harus dibuat di hadapan notaris, dan harus mendapatkan bukti pendaftaran badan hukum dari Kementerian Hukum dan Hak Asasi Manusia (KEMENKUMHAM).

\section{PROSES DAN METODE PENDIRIAN PERSEROAN TERBATAS}

Langkah yang pertama kali harus dilakukan para pendiri perseroan terbatas (PT) dalam pendirian perseroan terbatas (PT) adalah melakukan pertemuan dengan para pendiri untuk berdiskusi dan bermusyawarah terkait dengan akta pendirian perseroan terbatas (PT) yang ingin didirikan. Kemudian, para pendiri melakukan musyawarah untuk mencapai kemufakatan bersama. Setelah para pendiri sudah bersepakat, hal yang berikutnya harus dilakukan adalah menandatangani akta pendirian perseroan terbatas (PT) di hadapan notaris. Setelah akta pendirian perseroan terbatas (PT) sudah ditandatangani, pejabat yang memiliki kewenangan harus mengesahkan akta pendirian perseroan terbatas (PT) tersebut. Dalam hal ini, pejabat yang memiliki kewenangan tersebut adalah notaris. Selanjutnya, berikut ini adalah hal-hal yang harus tercantum di dalam akta pendirian perseroan terbatas (PT): ${ }^{10}$

1) Akta pendirian memuat anggaran dasar dan keterangan lain yang berkaitan dengan pendirian perseroan terbatas (PT);

\footnotetext{
${ }^{10}$ UU PT 2007 Pasal 8, UU Nomor 40 Tahun 2007 Pasal 8.
} 
2) Keterangan lain sebagaimana dimaksud pada pernyataan sebelumnya memuat sekurang-kurangnya:

a. Nama lengkap, tempat dan tanggal lahir, pekerjaan, tempat tinggal, dan kewarganegaraan pendiri perseorangan, atau nama, tempat kedudukan dan alamat lengkap serta nomor dan tanggal keputusan menteri mengenai pengesahan badan hukum dari pendiri perseroan terbatas (PT);

b. Nama lengkap, tempat dan tanggal lahir, pekerjaan, tempat tinggal, kewarganegaraan anggota direksi dan dewan komisaris yang pertama kali diangkat;

c. Nama pemegang saham yang telah mengambil bagian saham, rincian jumlah saham, dan nilai nominal saham yang telah ditempatkan dan disetorkan

Setelah segala proses mengenai pengesahan anggaran dasar perseroan terbatas (PT) diselesaikan, prosedur yang selanjutnya harus dijalani adalah proses pengesahan badan hukum. Untuk melanjutkan ke tahap proses pengesahan badan hukum, hal-hal yang perlu untuk dilakukan adalah: Pemohon harus mengajukan permohonan untuk memakai nama perseroan melalui Sistem Administrasi Badan Hukum (SABH); Ketentuan pemakaian nama yang diajukan paling sedikit memuat: a.) Nomor pembayaran persetujuan pemakaian nama perseroan dari bank persepsi, dan b.) Nama Perseroan yang dipesan; Nama perseroan harus mengikuti ketentuan perundang-undangan yang sesuai; Pemohon harus membayar biaya permohonan untuk memakai perseroan sesuai dengan ketentuan Kementerian Hukum dan Hak Asasi Manusia (KEMENKUMHAM); Mengisi formulir untuk menyatakan bahwa nama yang dipesan sudah sesuai; Setelah nama sudah disetujui oleh menteri, pemohon kemudian mengajukan permohonan untuk pengesahan badan hukum pada menteri secara elektronik paling lama 60 hari setelah akta pendirian ditandatangani; Pemohon juga harus menyertakan dokumen pendukung yang berupa dokumen untuk pendirian perseroan yang disimpan notaris; Kemudian, pemohon harus membayar biaya permohonan pengesahan dengan ketentuan yang diberikan oleh Kementerian Hukum dan Hak Asasi Manusia (KEMENKUMHAM); Setelah paling lama 14 hari surat pernyataan permohonan diberikan, menteri akan menerbitkan keputusan menteri mengenai pengesahan badan hukum secara elektronik; Kemudian, notaris dapat langsung mencetak keputusan Menteri tersebut dengan kertas berjenis F4 atau kertas folio, dan kemudian setelah dicetak, notaris wajib untuk langsung menandatangani dan membubuhi cap jabatan notaris, dan juga memuat kalimat yang menyatakan bahwa keputusan menteri ini dicetak dari Sistem Administrasi Badan Hukum (SABH).

Langkah selanjutnya adalah langkah yang harus ditempuh untuk mendaftarkan perseroan terbatas (PT). Untuk mendaftarkan perseroan terbatas (PT), harus dilakukan pendaftaran perusahaan. Pendaftaran perusahaan adalah tahapan proses yang harus dilakukan untuk mendapatkan legalitas dalam memiliki dan menjalankan sebuah perusahaan, khususnya perusahaan yang menjadi topik pembahasan kali ini, yaitu perseroan terbatas (PT). Pendaftaran perusahaan ini tentunya dilaksanakan oleh pejabat yang memiliki kewenangan. Sebelum diberlakukannya Undang-Undang Nomor 11 Tahun 2020 tentang Cipta Kerja (UU CK), pendaftaran perusahaan dilakukan dengan Wajib Daftar Perusahaan (WDP) yang diberlakukan dengan UndangUndang Nomor 3 Tahun 1982 tentang Wajib Daftar Perusahaan (UU WDP). 
Namun, kini Undang-Undang Nomor 3 Tahun 1982 Wajib Daftar Perusahaan (WDP) tersebut sudah digantikan dengan ketentuan perundang-undangan yang berada dalam Undang-Undang Nomor 11 Tahun 2020 tentang Cipta Kerja (UU CK), sehingga lembaran negara terkait Wajib Daftar Perusahaan (WDP) dicabut dan dinyatakan sudah tidak berlaku. ${ }^{11}$ Beberapa tahun belakangan ini, jajaran pemerintahan di Indonesia sedang aktif melakukan perubahan-perubahan dengan tahapan-tahapan kepada kemudahan prosedur untuk melakukan usaha. Online Single Submission (OSS) merupakan salah satu ide inovasi cemerlang yang dijadikan satu-satunya sarana untuk mendaftarkan perusahaan yang dirilis pada tahun 2018 lalu. Dengan sarana sistem Online Single Submission (OSS), para calon pelaku usaha maupun orang yang sudah menjalankan usaha diperkenalkan dengan adanya Nomor Induk Berusaha (NIB) yang diwajibkan bagi siapapun yang nantinya akan menjadi pelaku usaha ataupun yang sudah menjalanlan usahanya. Ketentuan ini berlaku untuk seluruh jenis badan usaha, termasuk juga termasuk perseroan terbatas (PT). Nomor Induk Berusaha (NIB) berfungsi sebagai persyaratan di saat akan mengajukan izin usaha di Online Single Submission (OSS). Selain itu, Nomor Induk Berusaha (NIB) yang sudah dimiliki dapat digunakan juga menjadi Tanda Daftar Perusahaan (TDP), Angka Pengenal Impor (API), serta hak untuk mengakses kepabeanan. Dengan demikian, saat proses pendirian perseroan terbatas (PT) diselesaikan, supaya perusahaan langsung bisa dijalankan untuk melakukan kegiatan usaha, maka si pelaku usaha hanya tinggal melakukan pengajuan Nomor Induk Berusaha (NIB) dan perizinan untuk melakukan kegiatan usaha bagi perseroan terbatas (PT) tersebut dengan cara mengakses secara elektronik atau daring melalui Online Single Submission (OSS). Hal tersebut dapat dilaksanakan tanpa harus merasa kerepotan atau bingung karena harus pergi berpindah-pindah dari satu kantor instansi ke kantor instansi lainnya dengan membawa tumpukan berkas dokumen yang harus diurus. Tahapan-tahapan yang terdapat pada Online Single Submission (OSS) ini dapat dikatakan membantu dalam manajemen waktu yang singkat dan langkah-langkah pendirian perseroan terbatas (PT) yang cepat. Sejak awal dirilis sampai dengan sekarang, sistem Online Single Submission (OSS) sudah melewati berbagai macam proses penyempurnaan yang berfungsi untuk memberikan kemudahan bagi dan membantu untuk menjelaskan kepada para pengguna terkait dengan Langkah-langkah yang harus dilakukan untuk memperoleh izin untuk melakukan kegiatan usaha. Pembaharuan terkini terkait dengan Online Single Submission (OSS) adalah pembaharuan sistem aplikasi dari Online Single Submission (OSS) versi 1.0 menjadi versi terbaru yaitu, Online Single Submission (OSS) 1.1. Sebagaimana yang sebelumnya telah disebutkan di atas, setelah kemunculan Online Single Submission (OSS), masyarakat telah mengetahui dan memahami bahwa Nomor Induk Berusaha (NIB) adalah sebuah bentuk perizinan usaha yang menjadi identitas si pelaku usaha yang didapatkan dari Lembaga Online Single Submission (OSS) setelah si pelaku usaha tersebut mendaftarkan perusahaannya dan kini diberlakukan juga sebagai Tanda Daftar Perusahaan (TDP). Jauh sebelum adanya Online Single Submission (OSS), Tanda Daftar Perusahaan (TDP) merupakan sebuah ketentuan perizinan untuk melakukan kegiatan usaha yang tentunya wajib disandang oleh sebuah badan usaha. Setelah diberlakukannya Undang-Undang Nomor

\footnotetext{
${ }^{11}$ UU CK 2020 Pasal 116, UU Cipta Kerja Pasal 116.
} 
11 Tahun 2020 tentang Cipta Kerja (UU CK) yang telah mencabut ketentuan terkait Wajib Daftar Perusahaan (WDP), kini dokumen terkait Tanda Daftar Perusahaan (TDP) hanyalah sebuah sejarah karena telah digantikan oleh Nomor Induk Berusaha (NIB) yang telah dirilis oleh Lembaga Online Single Submission (OSS).

Langkah terakhir yang harus diperhatikan dan dilaksanakan adalah pengumuman dari Kementerian Hukum dan Hak Asasi Manusia (KEMENKUMHAM) yang sehubungan dengan tambahan dalam Berita Negara Republik Indonesia (BNRI) terkait dengan pengumuman akta pendirian perseroan terbatas (PT). Selanjutnya, supaya sebuah perseroan terbatas (PT) bisa memperoleh Tambahan Berita Negara Republik Indonesia (BNRI) dari akta pendirian perseroan terbatas (PT), hal yang pertama kali harus dilakukan adalah, si pemohon harus mengajukan permohonan atas akta pendirian perseroan terbatas (PT) yang dimilikinya lebih dahulu agar dapat mendapatkan keputusan dari menteri terkait dengan pengesahan badan hukum perseroan terbatas (PT) tersebut. ${ }^{12}$ Jika Kementerian Hukum dan Hak Asasi Manusia (KEMENKUMHAM) telah mengeluarkan keputusan terkait dengan sahnya status badan hukum perseroan terbatas (PT), maka selanjutnya pengumuman terkait dengan Tambahan Berita Negara Republik Indonesia (BNRI) paling lama akan diumumkan dalam jangka waktu 14 hari yang dihitung setelah dikeluarkannya keputusan terkait dengan pengesahan status badan hukum perseroan terbatas (PT) oleh Kementerian Hukum dan Hak Asasi Manusia (KEMENKUMHAM). ${ }^{13}$ Tambahan Berita Negara Republik Indonesia (BNRI) seperti yang telah dijelaskan di atas selanjutnya akan diberikan kepada dewan direksi perseroan terbatas (PT) yang berwenang melalui seorang notaris dengan jumlah 25 lembar salinan.

\section{PERALIHAN TANGGUNGJAWAB TERBATAS PEMEGANG SAHAM MENJADI TANGGUNGJAWAB TAK TERBATAS PADA PERSEROAN TERBATAS}

Dalam situasi dan peristiwa tertentu berlaku prinsip pemisahan perusahaan dari pemegang saham. Stok perlu dihapus dan dihapus berdasarkan kasus per kasus, melanggar hambatan sosial atau tabir terhadap payung kewajiban terbatas. Akibat hukum terbongkarnya selubung atau tembok pelindung yang biasa disebut dengan istilah corporate veil. Dengan kata lain, prinsip tanggung jawab perseroan terbatas tidak berlaku tanpa syarat.

Hukum positif Indonesia berpeluang mengecualikan asas tanggung jawab terbatas. Sebagaimana disebutkan dalam Pasal 3 Ayat (2) Companies Act (UU PT) 2007:

a) Persyaratan badan hukum atau PT terpenuhi atau tidak terpenuhi. Ketentuan mengenai tanggung jawab beracara atas nama perusahaan yang belum memperoleh status badan hukum mengacu pada Pasal 14 Undang-Undang Nomor 40 Tahun 2007 dan dapat diklasifikasikan sebagai berikut: ${ }^{14}$

1) Proses persidangan dilakukan oleh semua anggota pengurus, bersama dengan semua pendiri dan semua anggota pengurus. UU

\footnotetext{
12 UU PT 2007 Pasal 28, UU Nomor 40 Tahun 2007 Pasal 28.

${ }^{13}$ Permenkumham 01 Tahun 2010 Pasal 9 ayat (3), Peraturan Menteri Hukum dan Hak Asasi Manusia Republik Indonesia Nomor M.HH-02.AH.01.01 Tahun 2010.

${ }^{14}$ Abdul Rasyid Saliman, Hukum Bisnis Untuk Perusahaan: Teori Dan Contoh.
} 
PT, Pasal 14 Ayat (1) Tahun 2007 menyatakan bahwa proses atas nama perusahaan yang tidak berhubungan harus disetujui oleh semua pendiri, direktur, dan anggota Komisi. Oleh karena itu, para pendiri, anggota direksi, dan anggota komite bertanggung jawab.

2) Proses diajukan oleh pendiri atas nama perusahaan. Jika pendiri mengajukan gugatan atas nama perseroan yang belum memperoleh bentuk badan hukum, maka perkara tersebut tidak mengikat perseroan sesuai dengan Pasal 14 ayat (2) UU PT 2007 yang menyatakan Pertanggungjawaban Pribadi masing-masing pendiri.

3) Pasal 3 (2) Undang-Undang PT No 40 Tahun 2007 dan Pasal 3 ayat (2), di mana pemegang saham bertanggung jawab secara pribadi jika persyaratan perusahaan sebagai badan hukum tidak terpenuhi atau tidak terpenuhi. Ketentuan UU Perseroan Terbatas 1995 dan UU Perseroan Terbatas 2007, serta Pasal 39 KUHD, menyatakan: Seseorang untuk seseorang, setiap orang bertanggung jawab atas tindakannya terhadap pihak ketiga secara keseluruhan.

4) KUHD tidak bertanggung jawab kepada pemegang saham jika mereka adalah satu-satunya pemegang saham. Namun, pada tahun 1973 (sebelum Undang-Undang Nomor 1 Tahun 1995 berlaku), Mahkamah Agung Republik Indonesia memiliki pendapat yang sama dengan Pengadilan Tinggi di Jakarta yang memiliki satu pemegang saham. Penyelesaian utang dapat disita. $^{15}$

b) Para pemegang saham yang terlibat menggunakan perusahaan secara langsung atau tidak langsung dengan niat jahat hanya untuk keuntungan pribadi. Ada penyalahgunaan atau penyalahgunaan, terutama jika Anda melihat tanda-tanda berikut:

1) Penipuan kreditur (creditor fraud).

2) Insufficient capital (modal tipis) Artinya, perusahaan kekurangan modal atau dalam keadaan "insufficient capital".

3) Perampokan adalah pemindahan kekayaan suatu perusahaan kepada pemegang saham, yang tidak lebih dari suatu perjanjian transaksi yang tidak sah antara perusahaan dengan pemegang saham untuk menipu kreditur.

4) Misalnya, menghindari hukum (menghindari hukum) melarang perusahaan dari ritel di mana saja. Untuk menghindari larangan tersebut, semua aset dimiliki oleh perusahaan.

5) Menghindari kewajiban yang ada. Menghindari pemenuhan kewajiban melalui perjanjian dengan pihak ketiga (kreditur). Hal ini sering dilakukan melalui pendirian anak perusahaan. Perusahaan baru atau anak perusahaan mengaku tidak ada hubungannya dengan perusahaan lama. (Perusahaan Induk) Kami tidak bertanggung jawab atas kontrak perusahaan lama, tetapi tetap melanjutkan bisnis masalah lama.

15 Rajagukguk, "Konsep Dan Perkembangan Pemikiran Tentang Tanggung Jawab Sosial Perusahaan." 
c) Pemegang saham terafiliasi terlibat dalam kegiatan ilegal oleh perusahaan. Ketika seorang pemegang saham bergabung atau berkolusi dengan suatu perusahaan dan melakukan perbuatan melawan hukum yang merugikan pihak lain. Menerapkan alasan ini tidak rumit. Faktafakta yang membuktikan keterlibatan pemegang saham dalam pelanggaran hukum yang dilakukan oleh perusahaan menjadi bahan bukti.

d) Aset perusahaan tidak cukup untuk membayar hutang perusahaan, karena pemegang saham yang terlibat menggunakan aset perusahaan secara langsung atau tidak langsung secara ilegal.

Dari adanya keempat isi Pasal 3 UU PT tersebut, terdapat beberapa hal yang menyebabkan terjadinya piercing the corporate veil yaitu: ${ }^{16}$

1) Dalam kasus pertama ini, jelas bahwa pemegang saham tidak serius menginginkan perseroan terbatas. Hal ini hanya dapat dicapai jika perseroan terbatas didirikan dan disetujui oleh Menteri Hukum dan Hak Asasi Manusia. Dengan mengabaikan proses dan prosedur yang harus diikuti, pendiri perseroan terbatas sebenarnya tidak bermaksud untuk mendirikan perseroan terbatas. Selain itu, dalam ketentuan Pasal 10 Ayat 9 UU No. PT. Menurut Pasal 40 Tahun 2007, perolehan badan hukum dan permohonan badan hukum tidak akan diajukan kepada Menteri Hukum dan Hak Asasi Manusia dalam jangka waktu 60 hari sejak tanggal akta pendirian, sehingga pendirian setelah jangka waktu tersebut menjadi tidak sah dan hukum dan likuidasi menjadi batal.Perusahaan tidak berstatus badan hukum dilikuidasi seperti yang dilakukan oleh pendiri. Tidak diperolehnya badan hukum bukan hanya karena belum dilakukan pengesahan sebagai badan hukum, tetapi juga karena berbagai alasan. Hal ini karena, misalnya, pendiri tidak ingin memberikan kontribusi modal yang telah ditentukan sebelumnya dan oleh karena itu tidak ingin bekerja untuk perusahaan, tetapi tidak mengizinkan pendiri untuk melakukan kegiatan yang diperlukan untuk manajemen. Hal ini dapat terjadi. segera;

2) Yang kedua terkait dengan teori keagenan bahwa pemegang saham telah secara jahat menggunakan perusahaan untuk keuntungan pribadi mereka. Pemegang saham dalam hal ini mengungsi di belakang perseroan terbatas, tetapi perseroan sendiri digunakan untuk keuntungan pribadi. Oleh karena itu, jelas bahwa kami adalah pemegang saham yang dilindungi secara hukum tanpa ketulusan dalam hal ini. Dalam hal ini penetrasi corporate denial berlaku bagi pemegang saham yang memanfaatkan perusahaan untuk keuntungan pribadi.

3) Poin ketiga ini menunjukkan aktivitas ilegal (penipuan) pemegang saham. Dalam hal ini, Anda perlu memperhatikan penilaian bahwa orang yang menyebabkan kerusakan pada orang lain bertanggung jawab atas kerusakan yang disebabkan olehnya. Sebagai orang artifisial, perseroan terbatas tidak memiliki wasiat. Dalam situasi di

\footnotetext{
${ }^{16}$ Gunawan Widjaja, "Risiko Hukum Sebagai Direksi, Komisaris Dan Pemilik PT : Piercing the Corporate Veil : Memberlakukan Tanggung Jawab Pribadi Pemegang Saham, Direksi \& Dewan Komisaris Menurut UU PT No. 40 Thn 2007.”
} 
mana kehendak masyarakat adalah kehendak pemegang saham, jelas bahwa pemegang saham bertanggung jawab.

4) Poin keempat terkait dengan penggunaan aset secara ilegal, yang mengurangi aset perusahaan dan mencegah perusahaan membayar semua kewajibannya kepada kreditur perusahaan.

Ketentuan Pasal 3 Ayat 2 UU PT. 40 Tahun 2007 tentang perseroan terbatas tidak mengatur pihak-pihak mana saja yang sebenarnya dilindungi oleh penerapan asas pengingkaran kepribadian hukum. Namun dengan memperhatikan ketentuan Pasal 3 (2) UU PT No. 40 Tahun 2007, terlihat bahwa perlindungan diberikan kepada kreditur PT. Dibandingkan dengan ketentuan Undang-Undang Perseroan Terbatas tersebut di atas, kami menyimpulkan bahwa hukum kasus common law memiliki tiga prinsip umum tentang kemungkinan melanggar prinsip tanggung jawab terbatas atau melanggar hukum pengingkaran kepribadian hukum, terlampir:

1) Doktrin "instrumentalitas". Pendekatan ini melibatkan tiga faktor:

a) PT tidak memiliki entitas independen karena ada pengendalian/pengendalian atas PT.

b) Manajemen mempengaruhi pelanggaran tugas.

c) Kelalaian menyebabkan kerusakan.

2) Doktrin "alter ego" bahwa hukum pengingkaran kepribadian hukum berlaku sehubungan dengan hal-hal berikut:

a) Kepentingan pemegang saham melebihi kepentingan PT kapan.

b) Sulit untuk membedakan atau mengenali unit individu pemegang saham dan unit PT terkait.

3) Doktrin "identitas" itu memunculkan isu penyatuan atau pemisahan aset perusahaan dalam kasus-kasus individual.

Sebagaimana dapat dilihat dari penjelasan dalam Pasal 3 Ayat 2, tujuan penghapusan perseroan terbatas adalah agar perseroan terbatas tidak boleh didirikan hanya sebagai sarana untuk mencapai tujuan pribadi para pemegang saham. Pastikan kekayaan pribadi pemegang saham dan kekayaan PT tercampur atau tidak ada perbedaan antara kekayaan pemegang saham dan kekayaan PT

\section{SIMPULAN DAN SARAN}

\section{A. Kesimpulan}

Tanggung jawab pemegang saham menurut hukum positif pada dasarnya terbatas pada modal disetor atau modal yang dimiliki (saham). Hal ini disebabkan oleh tiga ketentuan undang-undang: Kitab Undang-undang Hukum Dagang (KUHD), UU PT No. 1 Tahun 1995, dan UU PT No. 40 Tahun 2007, masing-masing tertulis sebagai berikut: KUHD menyatakan bahwa "Persero atau pemegang saham atau pemegang saham tidak bertanggung jawab lebih dari seluruh jumlah saham." Kedua, Pasal 3 UU No. PT. 1 Tahun 1995 menyatakan bahwa "Pemegang Saham tidak bertanggung jawab secara pribadi atas segala pengaturan yang dibuat atas nama PT dan tidak bertanggung jawab atas kerugian PT yang melebihi nilai saham yang diakuisisi”. Undang-Undang 40 Perusahaan tahun 2007 menyatakan bahwa "Pemegang saham tidak bertanggung jawab secara pribadi atas kewajiban yang dibuat untuk perseroan dan tidak bertanggung jawab atas kerugian perseroan yang melebihi jumlah saham yang dimiliki".

Apabila pemegang saham bertanggung jawab secara pribadi atas kerugian perseroan terbatas, hal ini ditentukan dalam ketentuan Pasal 3 Ayat 
2 UU PT No 1 Tahun 1995 dan UU No 40 Tahun 2007. meningkat. Jika persyaratan perusahaan atau PT sebagai badan hukum tidak terpenuhi atau tidak terpenuhi. Para pemegang saham yang terlibat menggunakan perusahaan secara langsung atau tidak langsung dengan niat jahat hanya untuk keuntungan pribadi. Pemegang saham terkait terlibat dalam kegiatan ilegal perusahaan. Dan pemegang unit terkait, secara langsung atau tidak langsung, secara tidak sah.

Aset perusahaan, dan akibatnya, aset perusahaan tidak cukup untuk memisahkan diri utang perusahaan. Selain ketentuan Pasal 3 Ayat 2, UU No. 1 Tahun 1995 tentang PT dan UU No. 1 tentang PT harus disampaikan secara tertulis. 40 Tahun 2007 juga diatur dalam Pasal 39 KUHD: "Kecuali didaftarkan dan diberitahukan, semua pengurus adalah orang perseorangan dan setiap orang bertanggung jawab atas perbuatannya terhadap pihak ketiga bertanggung jawab.

\section{DAFTAR PUSTAKA}

Abdul Rasyid Saliman. Hukum Bisnis Untuk Perusahaan: Teori Dan Contoh. Kencana, 2005.

Ayu Pramesti, S.H., Tri Jata. "Ulasan Lengkap : Tambahan Berita Negara Untuk Akta Pendirian PT Dan Yayasan.” Klinik: Hukum Perusahaan, 2015. https://www.hukumonline.com/klinik/detail/ulasan/lt5577e5bd683a9/tambah an-berita-negara-untuk-akta-pendirian-pt-dan-yayasan/\#_ftnref7.

Gunawan Widjaja, author. "Risiko Hukum Sebagai Direksi, Komisaris Dan Pemilik PT : Piercing the Corporate Veil : Memberlakukan Tanggung Jawab Pribadi Pemegang Saham, Direksi \& Dewan Komisaris Menurut UU PT No. 40 Thn 2007," 2008. http://lib.ui.ac.id.

Hadi, Zarman. "Karakteristik Tanggung Jawab Pribadi Pemegang Saham Komisaris Dan Direksi." UB Press, 2011.

Pengetahuan, Seputar. "Pengertian Badan Hukum, Ciri, Bentuk, Jenis Dan Teorinya," 2018. https://www.seputarpengetahuan.co.id/2018/01/pengertianbadan-hukum-ciri-ciri-bentuk-jenis-jenis-teori.html.

Permenkumham 01 Tahun 2010 Pasal 9 ayat (3). Peraturan Menteri Hukum dan Hak Asasi Manusia Republik Indonesia Nomor M.HH-02.AH.01.01 Tahun 2010 (2010).

Permenkumham Nomor 4 Tahun 2014. Peraturan Menteri Hukum dan Hak Asasi Manusia Nomor 4 Tahun 2014 (2014).

"Perpustakaan Unika Atma Jaya." Accessed December 12, 2021. https://lib.atmajaya.ac.id/default.aspx?tabID=470\&id=157443\&lok=1.

Rajagukguk, Erman. "Konsep Dan Perkembangan Pemikiran Tentang Tanggung Jawab Sosial Perusahaan." Jurnal Hukum IUS QUIA IUSTUM 15, no. 2 (2008). https://doi.org/10.20885/iustum.vol8.iss2.art1.

Subekti, R, and R Tjitrosudibio. "Kitab Undang-Undang Hukum Perdata Pasal 1320." In Kitab Undang-Undang Hukum Perdata: Burgerlijk Wetboek Dengan Tambahan Undang-Undang Pokok Agraria Dan Undang-Undang Perkawinan. Jakarta: Balai Pustaka, 2013.

_. "Kitab Undang-Undang Hukum Perdata Pasal 1653." In Kitab UndangUndang Hukum Perdata: Burgerlijk Wetboek Dengan Tambahan UndangUndang Pokok Agraria Dan Undang-Undang Perkawinan. Jakarta: Balai Pustaka, 2013.

Toha. "Pendirian PT Di Tahun 2021 Berdasarkan UU Cipta Kerja - Easybiz." Easybiz, 2021. https://www.easybiz.id/pendirian-pt-di-tahun-2021- 
berdasarkan-undang-undang-cipta-kerja/.

UU CK 2020 Pasal 109 ayat (1). UU Cipta Kerja Pasal 109 ayat (1) (2020).

UU CK 2020 Pasal 109 ayat (2). UU Cipta Kerja Pasal 109 ayat (2) (2020).

UU CK 2020 Pasal 116. UU Cipta Kerja Pasal 116, Pub. L. No. Pasal 116 (2020).

UU PT 2007 Pasal 1 angka 4. UU Nomor 40 Tahun 2007 Pasal 1 angka 4, Pub. L. No. Pasal 1 angka 4 (2007).

UU PT 2007 Pasal 1 angka 5. UU Nomor 40 Tahun 2007 Pasal 1 angka 5, Pub. L. No. Pasal 1 angka 5 (2007).

UU PT 2007 Pasal 1 angka 6. UU Nomor 40 Tahun 2007 Pasal 1 angka 6, Pub. L. No. Pasal 1 angka 6 (2007).

UU PT 2007 Pasal 108. UU Nomor 40 Tahun 2007 Pasal 108, Pub. L. No. Pasal 108 (2007).

UU PT 2007 Pasal 110. UU Nomor 40 Tahun 2007 Pasal 110, Pub. L. No. Pasal 110 (2007).

UU PT 2007 Pasal 2. UU Nomor 40 Tahun 2007 Pasal 2 (2007).

UU PT 2007 Pasal 28. UU Nomor 40 Tahun 2007 Pasal 28, Pub. L. No. Pasal 28 (2007).

UU PT 2007 Pasal 3 ayat (1). UU Nomor 40 Tahun 2007 Pasal 3 ayat (1), Pub. L. No. Pasal 3 ayat (1) (2007).

UU PT 2007 Pasal 76. UU Nomor 40 Tahun 2007 Pasal 76, Pub. L. No. Pasal 76 (2007).

UU PT 2007 Pasal 77. UU Nomor 40 Tahun 2007 Pasal 77, Pub. L. No. Pasal 77 (2007).

UU PT 2007 Pasal 78. UU Nomor 40 Tahun 2007 Pasal 78, Pub. L. No. Pasal 78 (2007).

UU PT 2007 Pasal 8. UU Nomor 40 Tahun 2007 Pasal 8, Pub. L. No. Pasal 8 (2007).

UU PT 2007 Pasal 92. UU Nomor 40 Tahun 2007 Pasal 92, Pub. L. No. Pasal 92 (2007).

UU PT 2007 Pasal 93. UU Nomor 40 Tahun 2007 Pasal 93, Pub. L. No. Pasal 93 (2007).

UU RI. Undang-Undang Nomor 1 Tahun 1995 tentang Perseroan Terbatas, Pub. L. No. Pasal 1 angka 1 (1995).

UUD 1945. UUD 1945 Pasal 1 ayat (1), Pub. L. No. Pasal 1 ayat (1) (1945).

—. UUD 1945 Pasal 18 ayat (1), Pub. L. No. Pasal 18 ayat (1) (1945). 